\title{
PENGARUH KOMPETENSI, INDEPENDENSI DAN PENGALAMAN TERHADAP KUALITAS AUDIT APARAT INSPEKTORAT KOTA TOMOHON DALAM PENGAWASAN PENGELOLAAN KEUANGAN DAERAH
}

\author{
Marietta Sylvie Bolang \\ Jullie J Sondakh \\ Jenny Morasa
}

\begin{abstract}
This study examined the influence of the auditors' competency, independency, and experiences towards audit quality of financial auditing of the staff of inspectorate in Tomohon City as part of their supervision function. The finding of this study could be an important input for improving the quality of financial management of the local government since the policy of decentralization has given the local governments authority not only to manage natural resources but also their financial sector. However, as could be seen there are still a lot of problems related to financial management mostly caused by the poor knowledge and skills related to financial auditing of government officials responsible for this specific task. It is common to find inconsistency in the financial report of internal auditor (inspectorate) and external auditor, Supreme Audit Agency (Badan Pemeriksa Keuangan).

There were two variables in this study. Audit quality was the dependent variable (Y) while the independent variables elaborated into three variables, namely: auditor's competency (X1), auditor's independency (X2) and auditor's experiences (X3). There were 36 personnel of the Inspectorate's Office of Tomohon City participated as the sources of this study. Thus, the population of this research is the Tomohon City Regional Inspectorate officers. Data used in this study were primary and secondary data, while questioner and indepth interview as well as document study used as the data collection methods. The first consecutive methods employed to obtain primary data while the last used for obtaining secondary data. Both data analyzed using the multiple linear regression techniques.

This study found that the influence of independent variable which were competency, independency and experiences towards dependent variables which was audit quality was significant. The 0.645 value of coeficient determination showed the significant relationship between both variables. This means that the equation model used in this study found the significancy at about $64,5 \%$. The remaining proportion which was 35,5\% explained by the other factors which were not part of this model. After examining the hypotheses, it can be concluded that partially competency had positive influence but not too significant to the quality of the inspectorate officer. However, independency and experiences had a positive and significant influence to the auditing quality of the public servant working in the inspectorate's office.

This study recommends to improving the knowledge and skills of the public apparatus by conducting short courses and training in accounting and auditing.
\end{abstract}

Keywords: audit quality, competency, independency and experiences 


\section{PENDAHULUAN}

\subsection{Latar Belakang Masalah}

Kesadaran akan pentingnya lembaga inspektorat sebagai lembaga yang menjalankan fungsi pengawasan internal (auditor internal) pemerintahan semakin meningkat. Tujuan utamanya adalah untuk mewujudkan tata kelola pemerintahan yang baik (good governance) yang merupakan salah satu agenda utama reformasi sektor publik di Indonesia. Inspektorat merupakan salah satu unit yang melakukan audit/pemeriksaan terhadap pemerintah daerah. Inspektorat daerah mempunyai tugas menyelenggarakan kegiatan pengawasan umum pemerintah daerah dan tugas lain yang diberikan kepala daerah, sehingga dalam tugasnya inspektorat sama dengan auditor internal (Falah, 2005 dalam Efendy 2010). Boynton (dalam Efendy, 2010) menjelaskan bahwa fungsi auditor internal adalah melaksanakan fungsi pemeriksaan internal yang merupakan suatu fungsi penilaian yang independen dalam suatu organisasi untuk menguji dan mengevaluasi kegiatan organisasi yang dilakukan. Selain itu, auditor internal diharapkan dapat memberikan sumbangan bagi perbaikan efisiensi dan efektivitas dalam rangka peningkatan kinerja organisasi. Untuk dapat menjalankan fungsi ini, seorang auditor harus memiliki kompetensi, independensi dan pengalaman. Hal ini sangat penting mengingat pengelolaan keuangan pemerintah daerah banyak mendapat sorotan dengan maraknya pemberian opini oleh Badan Pemeriksa Keuangan (BPK).

Menurut Peraturan Walikota Tomohon Nomor 22 Tahun 2009 tentang Penjabaran Tugas Pokok dan Fungsi Susunan Organisasi Inspektorat Kota Tomohon, Inspektorat sebagai salah satu lembaga teknis di Kota Tomohon mempunyai tugas pokok melakukan pengawasan terhadap pelaksanaan urusan pemerintahan di daerah Kota Tomohon, pelaksanaan pembinaan atas penyelenggaraan pemerintahan daerah kota dan pelaksanaan urusan pemerintahan kota. Namun ada indikasi bahwa kualitas audit yang dilaksanakan oleh aparat Inspektorat Kota Tomohon dalam hal pengawasan pengelolaan keuangan daerah masih lemah. Indikatornya adalah masih banyak temuan audit yang tidak terdeteksi oleh aparat inspektorat sebagai auditor internal, akan tetapi ditemukan oleh auditor eksternal yaitu BPK.

Berdasarkan hasil temuan BPK (Tahun Anggaran 2011) terhadap Laporan Keuangan Pemerintah Daerah, antara lain didapatkan hasil berupa adanya ketidakpatuhan terhadap peraturan perundang-undangan, kecurangan, serta ketidakpatuhan dan kesalahan administrasi dalam hal pelaporan keuangan. Pengalaman tiga tahun terakhir, Kota Tomohon memperoleh penilaian disclaimer dari BPK dalam hal pengelolaan keuangan. Dengan adanya temuan tersebut, berarti kualitas audit aparat inspektorat Kota Tomohon sebagai auditor internal pemerintah dalam hal pengawasan pengelolaan keuangan daerah masih lemah dan perlu mendapatkan perhatian dari pemerintah daerah.

Berdasarkan uraian diatas maka dalam penelitian ini penulis tertarik mengambil judul

"Pengaruh Kompetensi, Independensi dan Pengalaman Terhadap Kualitas Audit Aparat Inspektorat Kota Tomohon Dalam Pengawasan Pengelolaan Keuangan Daerah.”

\subsection{Rumusan Masalah}

Masalah yang dapat dirumuskan dalam penelitian ini adalah sebagai berikut:

Apakah ada pengaruh dari ketiga variabel, kompetensi independensi dan pengalaman terhadap kualitas audit Inspektorat Kota Tomohon dalam pengawasan pengelolaan keuangan daerah?

Untuk mengetahui pengaruh dari variabel kompetensi, independensi dan pengalaman aparat terhadap kualitas audit Inspektorat dalam pengawasan pengelolaan keuangan daerah, baik secara terpisah maupun secara bersama-sama.

\subsection{Manfaat Penelitian}

1. Hasil penelitian ini diharapkan dapat memberikan informasi mengenai faktor-faktor yang mempengaruhi kualitas audit Inspektorat dalam pengawasan pengelolaan keuangan 
daerah, sehingga akan dapat dimanfaatkan oleh para pemegang kebijakan dalam hal ini pemerintah daerah dalam upaya peningkatan kualitas audit Inspektorat.

2. Sebagai masukan bagi Inspektorat dalam mendukung pelaksanaan otonomi daerah khususnya peranan Inspektorat dalam meningkatkan kinerjanya sebagai internal auditor/aparat pengawasan pengelolaan keuangan daerah.

3. Dapat menambah wawasan dan pengetahuan bagi peneliti dalam Akuntansi Sektor Publik khususnya dalam hal pemeriksaan dan pengawasan pengelolaan keuangan daerah.

4. Hasil penelitian ini juga diharapkan akan dapat memberikan sumbangan bagi penelitian berikutnya.

\section{LANDASAN TEORITIS}

\subsection{Pengertian Good Governance}

Good governance menurut Sapariyah 2011, merupakan tata kelola yang baik pada suatu usaha yang dilandasi oleh etika profesional dalam berusaha atau berkarya. Pemahaman good governance dapat didefinisikan dengan seberapa jauh pemahaman atas konsep tata kelola perusahaan atau organisasi yang baik oleh para auditor. Pemahaman good governance merupakan wujud penerimaan akan pentingnya suatu perangkat peraturan atau tata kelola yang baik untuk mengatur hubungan, fungsi dan kepentingan berbagai pihak dalam urusan bisnis maupun pelayanan publik. Pemahaman atas good governance adalah untuk menciptakan keunggulan manajemen kinerja baik pada perusahaan bisnis manufaktur (good corporate governance) ataupun perusahaan jasa, serta lembaga pelayanan publik atau pemerintahan (good government governance).

\subsection{Pengelolaan Keuangan Daerah}

Dalam azas umum Permendagri No. 13 tahun 2006 pasal 4 tentang Pedoman Pengelolaan Keuangan Daerah, dikatakan bahwa keuangan daerah dikelola secara tertib, taat pada peraturan perundang-undangan, efektif, efisien, ekonomis, transparan, dan bertanggung jawab dengan memperhatikan azas keadilan, kepatutan, dan manfaat untuk masyarakat. Pengelolaan keuangan daerah dibagi menjadi tiga proses besar, yakni: perencanaan (termasuk didalamnya aktifitas penetapan APBD/penganggaran), penatausahaan (proses pelaksanaan APBD) dan pelaporan (pertanggungjawaban APBD). Proses akuntansi merupakan bagian dari aktifitas pelaporan yang mengharuskan setiap pengguna anggaran/pengguna barang untuk melaporkan seluruh transaksi ke dalam laporan keuangan. Struktur APBD terdiri dari penerimaan daerah yang dirinci berdasarkan urusan pemerintah daerah, organisasi, kelompok, jenis, obyek, dan rincian obyek pendapatan. Sampai sejauh ini, di Indonesia belum di atur mengenai standar akuntansi keuangan pemerintah yang merupakan acuan untuk menyusun dan membuat pelaporan keuangan pemerintah (Efendy, 2010).

\subsection{Pengawasan Pengelolaan Keuangan Daerah}

Permendagri No. 13 tahun 2006 pasal 308, dikatakan bahwa pemerintah melakukan pembinaan dan pengawasan pengelolaan keuangan daerah kepada pemerintah daerah yang dikoordinasikan oleh Menteri Dalam Negeri. Dalam hal pengawasan terhadap pengelolaan keuangan daerah, good governance dan clean government diperlukan untuk mendukung terselenggaranya pemerintahan yang efektif, efisien, transparan, akuntabel, serta bersih dan bebas dari praktik-praktik Korupsi, Kolusi dan Nepotisme (KKN) serta untuk menjamin agar pelaksanaan kegiatan pemerintahan berjalan sesuai dengan rencana dan berdasarkan ketentuan peraturan perundang-undangan yang berlaku. Pengawasan terhadap penyelenggaran pemerintahan tersebut dapat dilakukan melalui pengawasan melekat, pengawasan masyarakat, dan pengawasan fungsional (Cahyat, 2004 dalam Efendy 2010).

Cahyat (2004) dalam Efendy 2010, berdasarkan obyek pengawasan, pengawasan terhadap pemerintah daerah dibagi menjadi tiga jenis, yaitu pengawasan produk hukum dan kebijakan daerah, pelaksanaan penyelenggaraan pemerintahan daerah serta produk hukum 
dan kebijakan keuangan daerah. Tugas pokok dan fungsi inspektorat daerah yaitu melakukan pengawasan keuangan. Beberapa kewenangan daerah yang menyangkut pengawasan terhadap keuangan dan aset daerah adalah pelaksanaan APBD, penerimaan pendapatan daerah dan Badan Usaha Daerah, pengadaan barang/jasa serta pemeliharaan/penghapusan barang/jasa, penelitian dan penilaian laporan pajak-pajak pribadi, penyelesaian ganti rugi, serta inventarisasi dan penelitian kekayaan pejabat di lingkungan pemerintah daerah.

\subsection{Kualitas Audit}

Menurut Peraturan Menteri Negara Pendayagunaan Aparatur Negara nomor PER/05/M.PAN/03/2008, pengukuran kualitas audit atas laporan keuangan, khususnya yang dilakukan oleh APIP, wajib menggunakan Standar Pemeriksaan Keuangan Negara (SPKN). Dalam lampiran 3 SPKN (Paragraf 7) disebutkan bahwa: "Besarnya manfaat yang diperoleh dari pekerjaan pemeriksaan tidak terletak pada temuan pemeriksaan yang dilaporkan atau rekomendasi yang dibuat, tetapi terletak pada efektivitas penyelesaian yang ditempuh oleh entitas yang diperiksa. Hal pengukuran kualitas audit memerlukan indikator-indikator antara lain kualitas proses, apakah audit dilakukan dengan cermat, sesuai prosedur, sambil terus mempertahankan sikap skeptis yang dibangun sejak awal pelaksanaan audit hingga pelaporan dan pemberian rekomendasi. Probabilitas auditor untuk menemukan dan melaporkan pelanggaran pada sistem akuntansi auditee, tergantung pada kemampuan teknis, independensi auditor dan pengalaman dalam melakukan pemeriksaan.

\subsection{Kompetensi}

Kompetensi yang diperlukan dalam proses audit tidak hanya berupa penguasaan terhadap standar akuntansi dan auditing, namun juga penguasaan terhadap objek yang akan diaudit berupa pengetahuan umum tentang lingkungan entitas, program, dan kegiatan yang diperiksa. Selain dua hal di atas, ada tidaknya program atau proses peningkatan keahlian dapat dijadikan indikator untuk mengukur tingkat kompetensi auditor. Berdasarkan uraian di atas dapat ditarik kesimpulan bahwa kompetensi auditor adalah pengetahuan, keahlian, dan ketrampilan yang dibutuhkan auditor untuk dapat melakukan audit secara objektif, cermat, intuitif, seksama dan jarang melakukan kesalahan.

\subsection{Independensi}

Arens, et al., (2000) dalam Efendy (2010), mendefinisikan independensi dalam pengauditan sebagai "Penggunaan cara pandang yang tidak bias dalam pelaksanaan pengujian audit, evaluasi hasil pengujian tersebut, dan pelaporan hasil temuan audit". Sedangkan menurut Mulyadi (2008:26) dalam Sapariyah (2011) Independensi berarti sikap mental yang bebas dari pengaruh, tidak dikendalikan oleh pihak lain dan tidak tergantung pada orang lain. Independensi juga berarti adanya kejujuran dalam diri auditor dalam mempertimbangkan fakta dan adanya pertimbangan yang objektif tidak memihak dalam diri auditor dalam merumuskan dan menyatakan pendapatnya.

\subsection{Pengalaman}

Knoers dan Haditono (1999) dalam Asih (2006: 12) mengatakan bahwa pengalaman merupakan suatu proses pembelajaran dan penambahan perkembangan potensi bertingkah laku baik dari pendidikan formal maupun non formal atau bisa juga diartikan sebagai suatu proses yang membawa seseorang kepada suatu pola tingkah laku yang lebih tinggi. Variabel pengalaman akan diukur dengan menggunakan indikator lamanya bekerja, frekuensi pekerjaan pemeriksaan yang telah dilakukan, dan banyaknya pelatihan yang telah diikutinya.

\subsection{Tinjauan Pustaka}

Aji (2009) dalam Bawono (2010) meneliti tentang faktor-faktor yang mempengaruhi kualitas audit ditinjau dari persepsi auditor atas independensi, pengalaman,dan akuntabilitas. Hasilnya adalah independensi, pengalaman, dan akuntabilitas berpengaruh secara simultan terhadap kualitas audit. Selain itu, variabel independensi dan akuntabilitas berpengaruh secara parsial terhadap kualitas audit dan variabel pengalaman tidak berpengaruh terhadap 
kualitas audit. Rahman (2009) dalam Bawono (2010) meneliti tentang pengaruh kompetensi, independensi, dan due profesional care terhadap kualitas audit. Hasilnya adalah ketiga variabel independen tersebut berpengaruh secara simultan terhadap kualitas audit.

Fahdi (2012) meneliti tentang pengaruh pengalaman kerja, independensi, obyektifitas, integritas, kompetensi, dan motivasi terhadap kualitas hasil pemeriksaan. Hasil penelitian yang dilakukan menunjukkan bahwa independensi dan motivasi berpengaruh positif dan signifikan terhadap kualitas hasil pemeriksaan. Sedangkan untuk pengalaman kerja, obyektifitas, integritas, dan kompetensi tidak berpengaruh signifikan terhadap kualitas hasil pemeriksaan.

Persamaan penelitian-penelitian ini dengan penelitian yang akan dilakukan terletak pada variabel dependen yang digunakan, yaitu: kualitas audit dan objek penelitian pada sektor publik yakni Pemerintah Kota Tomohon. Sedangkan yang menjadi perbedaan terletak pada variabel independen dimana penelitian ini fokus pada tiga variabel yakni: kompetensi, independensi dan pengalaman.

\section{KERANGKA KONSEPTUAL DAN HIPOTESIS \\ 3.1. Kerangka Konseptual Penelitian}

Gambar 3.1. Kerangka konseptual pengaruh kompetensi, independensi dan pengalaman terhadap kualitas audit aparat Inspektorat Kota Tomohon

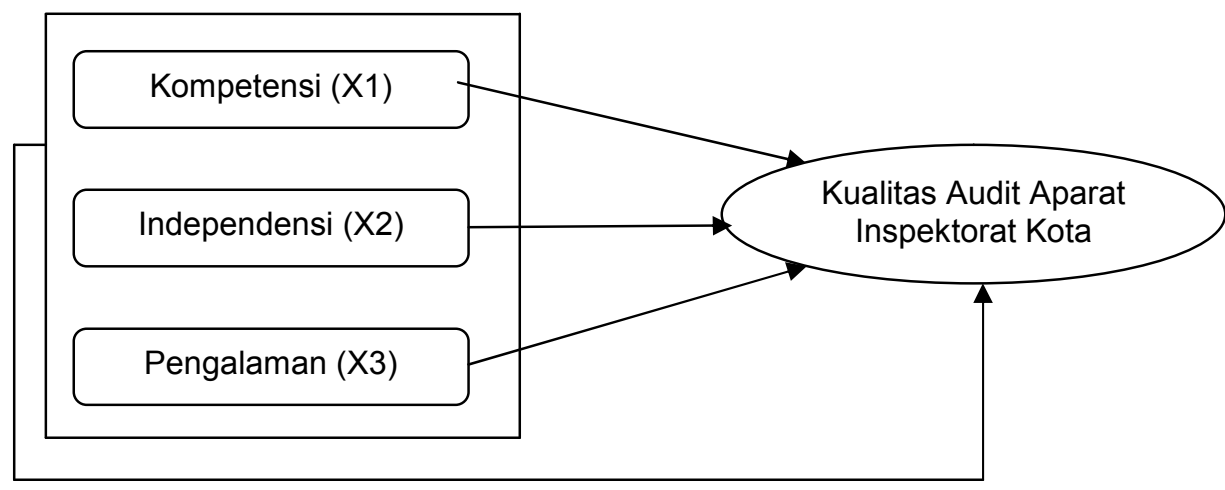

\subsection{Hipotesis}

Hipotesa yang diajukan dalam penelitian ini:

$\mathrm{H}_{1}$ : Kompetensi berpengaruh signifikan terhadap kualitas audit aparat Inspektorat di Kota Tomohon dalam pengawasan pengelolaan keuangan.

$\mathrm{H}_{2}$ : Independensi berpengaruh signifikan terhadap kualitas audit aparat Inspektorat di Kota Tomohon dalam pengawasan pengelolaan keuangan.

$\mathrm{H}_{3}$ : Pengalaman berpengaruh signifikan terhadap kualitas audit aparat Inspektorat di Kota Tomohon dalam pengawasan pengelolaan keuangan.

\section{METODE PENELITIAN}

\subsection{Jenis/ Rancangan Penelitian}

Jenis penelitian yang digunakan dalam penelitian ini adalah penelitian penjelasan (explanatory/confirmatory research) karena penelitian ini bermaksud untuk menjelaskan hubungan causal antara variabel-variabel dengan melalui pengujian hipotesis. Data yang digunakan dalam penelitian ini adalah data kuantitaf yaitu yang diambil dari kuesioner dan data kualitatif yang diperoleh dari wawancara.

\subsection{Populasi dan Sampel Penelitian}


Populasi dalam penelitian ini adalah seluruh aparat Inspektorat Kota Tomohon yang ikut dalam tugas pemeriksaan, yaitu sebanyak 36 orang. Karena jumlah populasi sedikit, maka semua populasi akan dijadikan sampel. Metode pemilihan sampel yang digunakan adalah metode sensus, dimana penyebaran kuesioner dilakukan pada semua populasi.

\subsection{Definisi Operasional dan Pengukuran Variabel}

Penelitian ini menggunakan tiga variabel independen (kompetensi, independensi dan pengalaman auditor) dan satu variabel dependen yakni kualitas audit.

Variabel-variabel tersebut di atas menggunakan kuesioner yang terdiri dari 21 pertanyaan dan diukur dengan skala Likert 1-5 untuk setiap bobot pertanyaan yaitu :

\begin{tabular}{|c|c|c|c|}
\hline 1 . & Sangat setuju (SS) & $=$ & Skor 5 \\
\hline 2. & Setuju (S) & $=$ & Skor 4 \\
\hline & $\operatorname{Netral}(\mathrm{N})$ & $=$ & Skor 3 \\
\hline & Tidak Setuju (TS) & $=$ & Skor 2 \\
\hline & Sangat Tidak Setuju (STS) & $=$ & Skor \\
\hline
\end{tabular}

\subsection{Lokasi dan Waktu Penelitian}

Penelitian ini dilakukan di Inspektorat Kota Tomohon pada bulan Maret 2012 sampai selesai di bulan September tahun 2012. Pemilihan Kota Tomohon sebagai lokasi penelitian didasarkan pada pertimbangan bahwa masih diperlukannya upaya peningkatan kualitas audit Inspektorat Kota Tomohon hal ini ditandai dengan adanya temuan dari BPK tentang pengelolaan keuangan daerah dan pemberian opini Disclaimer sejak tiga tahun berturut-turut (Tahun Anggaran 2009, Tahun Anggaran 2010 dan Tahun Anggaran 2011) .

\subsection{Teknik Pengumpulan Data}

Untuk mendapatkan data tentang variabel-variabel yang diungkapkan dalam penelitian ini, teknik pengumpulan data dan informasi melalui penyebaran kuesioner dan melakukan wawancara.

\subsection{Cara Pengolahan dan Teknik Analisis Data}

4.6.1. Cara Pengolahan Data

Statistik Deskriptif

\subsubsection{Teknik analisis Data}

1. Uji asumsi klasik, terdiri atas: uji Normalitas, uji multikolinieritas, uji heteroskedastisitas;

2. Uji hipotesis dilakukan dengan menggunakan model analisis regresi berganda. Untuk menguji pengaruh variabel independen terhadap variabel dependen dilakukan dengan uji simultan (Uji F) dan uji parsial (Uji t).

5. ANALISIS DAN PEMBAHASAN HASIL PENELITIAN

5.1. Statistik Responden

Tabel 5.1. Jenis Kelamin, Usia, Tingkat Pendidikan dan Masa Kerja responden

\begin{tabular}{|c|c|c|c|c|c|c|c|c|c|c|c|c|}
\hline $\begin{array}{c}\text { Jenis } \\
\text { Kelamin } \\
(\%)\end{array}$ & \multicolumn{4}{|c|}{$\begin{array}{c}\text { Usia } \\
(\%)\end{array}$} & \multicolumn{3}{c|}{ Tingkat Pendidikan } & \multicolumn{3}{c|}{$\begin{array}{c}\text { Masa Kerja } \\
(\%)\end{array}$} \\
\hline L & $\mathrm{P}$ & $<30$ & $30-40$ & $40-50$ & $>50$ & S2 & S1 & D3 & $\begin{array}{c}\text { SM } \\
\text { A }\end{array}$ & $<5$ th & $5-10$ th & $>10$ th \\
\hline 36,1 & 63,9 & 13,9 & 44,4 & 19,4 & 22,2 & 22,2 & 52,7 & 11,1 & 13,9 & 41,7 & 13,9 & 44,4 \\
\hline
\end{tabular}


Tabel 5.2. Latar Belakang Pendidikan Responden

\begin{tabular}{|c|c|c|c|c|c|c|c|}
\hline \multicolumn{8}{|c|}{ Latar Belakang Pendidikan } \\
\hline \multicolumn{6}{|c|}{ Ekonomi (S1) } & \multirow{2}{*}{\multicolumn{2}{|c|}{$\begin{array}{l}\text { Non Ekonomi } \\
\text { (D3, S1, S2) }\end{array}$}} \\
\hline \multicolumn{2}{|c|}{ Akuntansi } & \multicolumn{2}{|c|}{ Manajemen } & \multicolumn{2}{|c|}{ Ek. Pembangunan } & & \\
\hline Jumlah & $\%$ & Jumlah & $\%$ & Jumlah & $\%$ & Jumlah & $\%$ \\
\hline 1 & 2,77 & 6 & 16,66 & 1 & 2,77 & 28 & 77,77 \\
\hline
\end{tabular}

\subsection{Uji Asumsi Klasik}

\subsubsection{Uji Normalitas}

Gambar 5.1 Grafik Normal P-P Plot

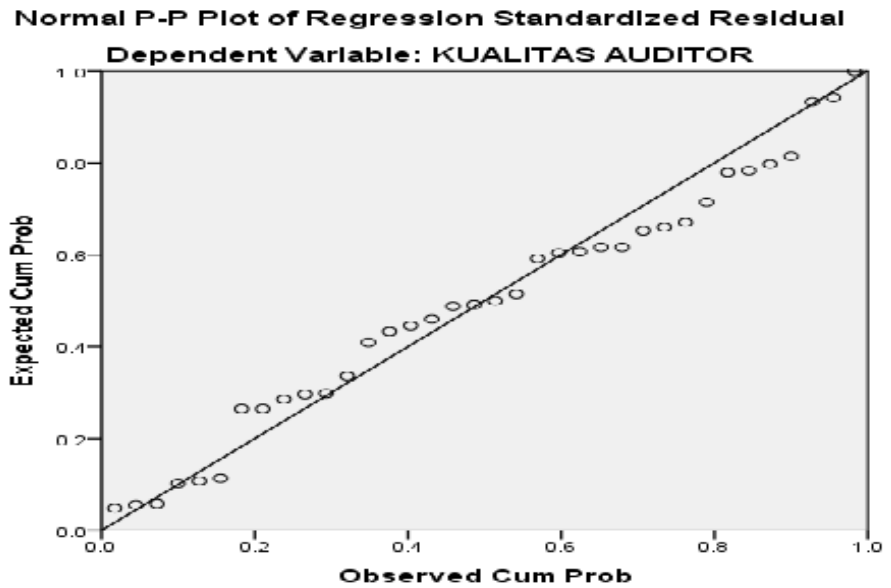

Sumber : Hasil Olahan,2012. Data SPSS Version 20.00.

Berdasarkan gambar 5.1. grafik normal plot, menunjukkan bahwa model regresi layak dipakai dalam penelitian ini karena pada grafik normal plot terlihat titik-titik menyebar di sekitar garis diagonal serta penyebarannya mengikuti arah garis diagonal sehingga memenuhi asumsi normalitas.

\subsubsection{Uji Multikolinearitas}

Tabel 5.3. Hasil Perhitungan Tolerance dan VIF Coefficients $^{\mathrm{a}}$

\begin{tabular}{|rl|r|r|}
\hline Model & & \multicolumn{2}{|c|}{ Collinearity Statistics } \\
\cline { 3 - 4 } & & Tolerance & \multicolumn{1}{c|}{ VIF } \\
\hline \multicolumn{2}{|c|}{ (Constant) } & .997 & 1.003 \\
KOMPETENSI & & .925 & 1.081 \\
1 & INDEPENDENSI & .925 & 1.081 \\
\hline & PENGALAMAN & & \\
\hline
\end{tabular}

Dependent Variable: KUALITAS AUDITOR

Sumber : data Hasil Olahan SPSS Version 20.00 


\subsubsection{Uji Heteroskedastisitas}

Gambar 5.2 Grafik Scatterplot

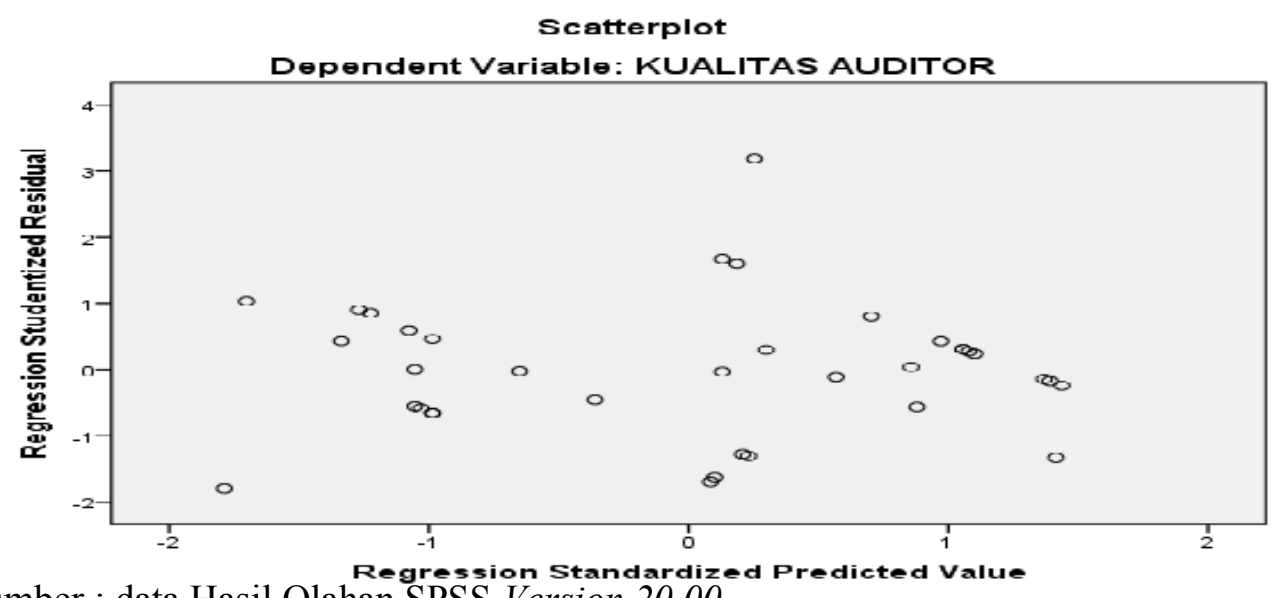

Sumber : data Hasil Olahan SPSS Version 20.00

Berdasarkan Gambar 5.2, dapat disimpulkan bahwa tidak terjadi heteroskedastisitas. Hal ini dapat dilihat berdasarkan gambar 5.2, dimana titik-titik yang ada dalam grafik tidak membentuk pola yang teratur atau tertentu yang jelas dan titik-titik tersebut tersebar diatas dan dibawah angka 0 pada sumbu $\mathrm{Y}$ sehingga dapat diindikasikan bahwa tidak terjadi heteroskedastisitas dalam model regresi ini.

\subsection{Uji Hipotesis}

\subsubsection{Analisis Regresi Berganda}

Hasil analisis regresi berganda yang diperoleh dari pengolahan data menggunakan SPSS 20.00 tampak pada Tabel 5.3. Berdasarkan tabel 5.3, maka menghasilkan

$$
Y=2,694+0,58 X_{1}+0,749 X_{2}+1,086 X_{3}+e
$$

Tabel 5.4. Hasil Regresi Berganda Coefficients $^{\mathrm{a}}$

\begin{tabular}{|c|c|c|c|c|c|c|}
\hline \multirow{2}{*}{\multicolumn{2}{|c|}{ Model }} & \multicolumn{2}{|c|}{ Unstandardized Coefficients } & Standardized & \multirow[t]{2}{*}{$\mathrm{T}$} & \multirow[t]{2}{*}{ Sig. } \\
\hline & & $B$ & Std. Error & Beta & & \\
\hline \multirow{4}{*}{1} & (Constant) & 2.694 & 4.955 & & .544 & .590 \\
\hline & KOMPETENSI & .058 & .150 & .039 & .390 & .699 \\
\hline & INDEPENDENSI & .749 & .186 & .422 & 4.035 & .000 \\
\hline & PENGALAMAN & 1.086 & .190 & .600 & 5.728 & .000 \\
\hline
\end{tabular}

Sumber : Data Olahan, 2012

Berdasarkan persamaan regresi berganda pada Tabel 5.3, dapat dilihat nilai konstanta (a) sebesar 2,694 dan bernilai positif, hal ini berarti besarnya Kualitas Auditor (Y) mempunyai hubungan positif atau searah dengan variabel Independen yaitu variabel Kompetensi (X1), Independensi (X2), dan Pengalaman (X3). Koefisien regresi Kompetensi (X1), sebesar 0,058 dan mempunyai nilai positif atau searah yang menunjukkan bahwa setiap adanya peningkatan variabel Kompetensi (X1), maka akan mengakibatkan peningkatan Kualitas Auditor (Y) dengan asumsi faktor lain konstan. Koefisien regresi Independensi (X2), sebesar 0,749 dan mempunyai nilai positif atau mempunyai hubungan searah yang menunjukkan bahwa setiap adanya peningkatan variabel Independensi (X2), maka akan mengakibatkan peningkatan Kualitas Auditor (Y) dengan asumsi faktor lain konstan. Koefisien regresi Pengalaman (X3), sebesar 1.086 dan mempunyai nilai positif atau mempunyai hubungan searah yang menunjukkan bahwa setiap adanya peningkatan variable 
Pengalaman (X3), maka akan mengakibatkan peningkatan Kualitas Auditor (Y) dengan asumsi faktor lain konstan.

\subsubsection{Uji F}

Dari hasil output uji koefisien regresi secara bersama-sama (Uji F) dapat diketahui nilai F seperti pada Tabel 5.5 berikut ini:

Tabel 5.5. Hasil Uji F

ANOVA $^{\mathrm{a}}$

\begin{tabular}{|rl|r|r|r|r|r|}
\hline Model & & Sum of Squares & df & Mean Square & F & Sig. \\
\hline \multirow{2}{*}{1} & Regression & 233.258 & 3 & 77.753 & 22.222 & $.000^{\mathrm{b}}$ \\
& Residual & 111.965 & 32 & 3.499 & & \\
& Total & 345.222 & 35 & & & \\
\hline
\end{tabular}

a. Dependent Variable: KUALITAS AUDITOR

b. Predictors: (Constant), PENGALAMAN, KOMPETENSI, INDEPENDENSI

Sumber : Data Olahan, 2012

Berdasarkan Tabel 5.5, hasil uji $\mathrm{F}$ diperoleh $\mathrm{F}_{\text {hitung }}$ sebesar $22.222>\mathrm{F}_{\text {tabel }}$ 1,764 dengan menggunakan tingkat signifikansi $\mathrm{P}=0,000<\alpha=0,05$ maka dapat disimpulkan bahwa kompetensi, independensi dan pengalaman secara bersama-sama berpengaruh signifikan terhadap kualitas audit aparat inspektorat di Kota Tomohon.

\subsubsection{Uji $t$}

Dari analisis regresi output dapat dilihat pada tabel 5.6, sebagai berikut:

Tabel 5.6. Hasil Uji t

Coefficients

\begin{tabular}{|l|r|r|r|r|r|}
\hline \multirow{2}{*}{ Model } & \multicolumn{2}{|c|}{ Unstandardized Coefficients } & Standardized Coefficients & \multirow{2}{*}{ Sig. } \\
\cline { 2 - 5 } & \multicolumn{1}{|c|}{$\mathrm{B}$} & Std. Error & Beta & & \\
\hline (Constant) & 2.694 & 4.955 & & .544 & .590 \\
KOMPETENSI & .058 & .150 & .039 & .390 & .699 \\
INDEPENDENSI & .749 & .186 & .422 & 4.035 & .000 \\
PENGALAMAN & 1.086 & .190 & .600 & 5.728 & .000 \\
\hline
\end{tabular}

sumber : Data Olahan, 2012

Tabel distribusi t dicari pada a $=5 \%: 2=2,5 \%$ (uji 2 sisi), dengan derajat kebebasan $\mathrm{df}=(\mathrm{n}-\mathrm{k}-1)$ atau $(36-3-1)=32$. Dengan pengujian 2 sisi $($ signifikansi $=0,025)$ hasil diperoleh untuk $t_{\text {tabel }}$ sebesar 2,355, dengan kriteria pengujian:

$$
\begin{aligned}
& \mathrm{H}_{0} \text { diterima jika } \mathrm{t}_{\text {hitung }}<\mathrm{t}_{\text {tabel }} \\
& \mathrm{H}_{0} \text { ditolak jika } \mathrm{t}_{\text {hitung }}>\mathrm{t}_{\text {tabel }}
\end{aligned}
$$

\section{Pengujian hipótesis 1}

Nilai $\mathrm{t}_{\text {hitung }}<\mathrm{t}_{\text {tabel }}(0,390<2,355)$ dan signifikansi $\mathrm{P}=0,699>\alpha=0,05$ maka $\mathrm{H}_{0}$ diterima, dan Ha ditolak artinya secara parsial berpengaruh tetapi tidak signifikan antara kompetensi $\left(\mathrm{X}_{1}\right)$ dan Kualitas Audit (Y).

\section{Pengujian hipótesis 2}

Nilai $\mathrm{t}_{\text {hitung }}>\mathrm{t}_{\text {tabel }}(4.035>2,355)$ dan signifikansi $\mathrm{P}=0,000<\alpha=0,05$ maka $\mathrm{H}_{0}$ ditolak dan Ha diterima, artinya secara parsial berpengaruh signifikan antara independensi $\left(\mathrm{X}_{2}\right)$ dan Kualitas Audit (Y).

\section{Pengujian hipótesis 3}

Nilai $\mathrm{t}_{\text {hitung }}>\mathrm{t}_{\text {tabel }}(5,728>2,355)$ dan signifikansi $\mathrm{P}=0,000>\alpha=0,05$ maka $\mathrm{H}_{0}$ ditolak dan $\mathrm{H}_{\mathrm{a}}$ diterima, artinya secara parsial berpengaruh signifikan antara pengalaman $\left(\mathrm{X}_{3}\right)$ dan Kualitas Audit (Y). 


\subsubsection{Koefisien Determinasi}

Hasil koefisien determinasi yang diperoleh dari pengolahan data menggunakan SPSS 20.00 tampak pada Tabel 5.7, sebagai berikut:

\section{Tabel 5.7. Hasil Koefisien Determinasi}

\begin{tabular}{|l|r|r|r|r|r|}
\hline Model & R & R Square & Adjusted R Square & $\begin{array}{c}\text { Std. Error of the } \\
\text { Estimate }\end{array}$ & Durbin-Watson \\
\hline 1 & $.822^{\mathrm{a}}$ & .676 & .645 & 1.87053 & 1.684 \\
\hline
\end{tabular}

a. Predictors: (Constant), PENGALAMAN, KOMPETENSI, INDEPENDENSI

b. Dependent Variable: KUALITAS AUDITOR

Sumber : Data Olahan, 2012

Hasil perhitungan koefisien determinasi menunjukkan bahwa nilai koefisien determinasi adalah 0,645. Hal ini menunjukkan bahwa besarnya pengaruh variabel independen, yaitu kompetensi, independensi dan pengalaman terhadap variabel dependen yaitu kualitas audit adalah sebesar $64,5 \%$, sedangkan sisanya sebesar 35,5\% dijelaskan oleh faktor-faktor lain yang tidak dimasukkan dalam model ini, misalnya akuntabilitas, etika, atau motivasi, tergantung penelitian yang dilakukan.

\subsection{Pembahasan}

\subsubsection{Pengaruh Kompetensi terhadap Kualitas Audit}

Hasil penelitian ini menolak hipotesis pertama yang menyebutkan bahwa kompetensi berpengaruh signifikan terhadap kualitas audit aparat Inspektorat di Kota Tomohon dalam pengawasan pengelolaan keuangan. Hasil penelitian yang didapat adalah kompetensi berpengaruh tidak signifikan terhadap kualitas audit namun mempunyai hubungan yang positif atau searah.

Hasil pengujian hipotesis ini tidak sejalan dengan yang dilakukan oleh Mansur (2007), Alim, dkk (2007), dan Efendy (2010) yang menyatakan bahwa kompetensi memiliki pengaruh yang signifikan terhadap kualitas audit, tetapi sejalan dengan penelitian yang dilakukan Fahdi (2012) yang menyatakan bahwa kompetensi tidak berpengaruh signifikan terhadap kualitas hasil pemeriksaan, alasannya karena masih kurangnya pengetahuan auditor dalam memahami entitas yang diaudit, kemudian kurangnya kemampuan auditor dalam menganalisa permasalahan.

\subsubsection{Pengaruh Independensi terhadap Kualitas Audit}

Hasil penelitian ini menerima hipotesis kedua bahwa independensi secara parsial berpengaruh signifikan terhadap kualitas audit dan mempunyai hubungan yang positif atau searah. Hal ini berarti bahwa semakin meningkatnya independensi seorang auditor akan meningkatkan kualitas audit, artinya kualitas audit dapat dicapai jika auditor memiliki independensi yang baik.

Hasil pengujian hipotesis ini sejalan dengan yang dilakukan oleh Mansur (2007), Alim dkk (2007), Aji (2009) dan Fahdi (2012) yang menyatakan bahwa variabel independensi berpengaruh positif dan signifikan terhadap kualitas audit.

\subsubsection{Pengaruh Pengalaman terhadap Kualitas Audit}

Hasil penelitian pada hipotesis ketiga ini menyatakan bahwa pengalaman secara parsial berpengaruh signifikan terhadap kualitas audit dan mempunyai hubungan yang positif atau searah. Adanya pengaruh positif variabel pengalaman berarti semakin tinggi tingkat pengalaman auditor semakin tinggi pula tingkat kualitas auditnya. Auditor yang berpengalaman cenderung memiliki ketelitian dan kemampuan yang baik dalam menyelesaikan setiap pekerjaannya.

Hasil penelitian ini sejalan dengan yang dikemukakan oleh Mansur (2007), yang menyebutkan bahwa pengalaman auditor berhubungan positif terhadap kualitas audit. 


\section{KESIMPULAN DAN SARAN}

\subsection{Kesimpulan}

Penelitian ini bertujuan untuk menganalisis pengaruh kompetensi, independensi, dan pengalaman aparat Inspektorat Kota Tomohon terhadap kualitas audit. Berdasarkan hasil penelitian maka dapat diambil kesimpulan sebagai berikut :

1. Kompetensi, independensi, dan pengalaman secara simultan berpengaruh positif terhadap kualitas audit yang dilaksanakan oleh aparat Inspektorat Kota Tomohon.

2. Kompetensi berpengaruh positif namun tidak signifikan terhadap kualitas audit, hal ini dapat dipahami sebab aparat inspektorat di Kota Tomohon (sesuai dengan data tingkat pendidikan yang diperoleh dalam kuesioner) banyak yang tidak memiliki latar belakang pendidikan formal di bidang akuntansi ataupun auditing.

3. Independensi secara parsial berpengaruh signifikan terhadap kualitas audit dan mempunyai hubungan yang positif atau searah. Hal ini berarti bahwa semakin meningkatnya independensi seorang auditor akan meningkatkan kualitas audit, artinya kualitas audit dapat dicapai jika auditor memiliki independensi yang baik.

4. Pengalaman secara parsial berpengaruh signifikan terhadap kualitas audit dan mempunyai hubungan yang positif atau searah. Adanya pengaruh positif variabel pengalaman berarti semakin tinggi tingkat pengalaman auditor semakin tinggi pula kualitas auditnya. Auditor yang berpengalaman cenderung memiliki ketelitian dan kemampuan yang baik dalam menyelesaikan setiap pekerjaannya.

\subsection{Saran}

Berdasarkan hasil penelitian yang telah dilakukan maka diajukan saran, antara lain:

1. Lembaga Inspektorat Kota Tomohon haruslah memperkuat timnya di dalam melakukan pengawasan dan pemeriksaan dengan sumber daya berupa tenaga ahli di bidang audit internal ataupun yang memiliki pendidikan yang memadai dalam bidang akuntansi dan auditing.

2. Mutasi antar satuan kerja sebaiknya tidak dilakukan terhadap aparat yang telah memiliki pengalaman dan sudah mengikuti berbagai pelatihan dalam hal audit.

3. Pola penugasan auditor dalam melakukan audit, sebaiknya dilakukan oleh auditor yang sudah berpengalaman dan dipandang mempunyai pengetahuan yang memadai. Apabila diberikan pada junior auditor sebaiknya didampingi oleh minimal seorang senior auditor, dengan maksud untuk menjaga kualitas dan kredibilitas hasil audit di mata para pengguna informasi laporan keuangan, sehingga dapat memberikan kesempatan kepada junior auditor untuk menambah pengalaman dan pengetahuannya sebagai seorang auditor. Disamping itu, harus dilakukan telaah hasil pemeriksaan auditor untuk menjamin bahwa pemeriksaan dan bentuk pelaporan yang dilakukan telah sesuai dengan standar profesional yang berlaku dan berkualitas.

4. Penempatan pegawai di lingkup Inspektorat Kota Tomohon sebaiknya berdasarkan fungsi dan kompetensi yang dimiliki.

5. Pada penelitian ini, variabel independen yang diteliti (kompetensi, independensi dan pengalaman) berpengaruh terhadap variabel kualitas audit sebagai variabel dependen sebesar $64,5 \%$, sedangkan sisanya sebesar $35,5 \%$ dijelaskan oleh faktor-faktor lain yang tidak dimasukkan dalam model ini. Penelitian selanjutnya disarankan untuk meneliti pengaruh variabel-variabel lain yang belum termasuk dalam model regresi pada penelitian ini, misalnya akuntabilitas, etika, ataupun motivasi.

\section{DAFTAR PUSTAKA}

Alim, M.N., T. Hapsari, dan L. Purwanti. 2007. Pengaruh Kompetensi dan Independensi terhadap Kualitas Audit dengan Etika Auditor sebagai Variabel Moderasi. Simposium Nasional Akuntansi X. Makassar. 
Asih, Dwi Ananing Tyas. 2006. Pengaruh Pengalaman Terhadap Peningkatan Keahlian Auditor Dalam Bidang Audit. Fakultas Ekonomi, Universitas Islam Indonesia, Yogyakarta. Skripsi. 2006.

Badan Pusat Statistik Kota Tomohon bekerja sama dengan BAPPEDA Kota Tomohon, 2012. Tomohon Dalam Angka (Tomohon in Figures) 2012. BPS Kota Tomohon. 2012.

Bawono, Icuk Rangga dan Elisha Muliani Singgih, 2010. Faktor-Faktor Dalam Diri Auditor dan Kualitas Audit: Studi Pada KAP 'Big Four' di Indonesia. Jurnal Bisnis dan Ekonomi 2010.

Christiawan, Y.J. 2002. Kompetensi dan Independensi Akuntan Publik: Refleksi Hasil Penelitian Empiris. Journal Directory : Kumpulan Jurnal Akuntansi dan Keuangan Unika Petra. Vol. 4 / No. 2.

Direktorat Jenderal Keuangan Daerah (DJKD), 2013. 300 Kepala Daerah Terjerat Kasus Korupsi, diakses 23 April 2013, $<$ http://djkd.kemendagri.go.id/?jenis $=n e w s \& p=$ detail berita\&id $=861>$

Efendy, Muh. Taufiq. 2010. Pengaruh Kompetensi, Independensi, dan Motivasi Terhadap Kualitas Audit Aparat Inspektorat Dalam Pengawasan Keuangan Daerah (Studi Empiris pada Pemerintah Kota Gorontalo).Tesis 2010.

Fahdi, Muhammad. 2012. Pengaruh Pengalaman Kerja, Independensi, Obyektifitas, Integritas, Kompetensi, dan Motivasi Terhadap Kualitas Hasil Pemeriksaan.Tesis 2012.

Lastanti Sri, Hexana. 2005. Tinjauan Terhadap Kompetensi dan Independensi Akuntan Publik : Refleksi Atas Skandal Keuangan. Media Riset Akuntansi, Auditing dan Informasi Vol.5 No.1 April 2005.

Mansur, Tubagus. 2007. Faktor-faktor yang mempengaruhi kualitas audit ditinjau dari persepsi auditor atas pelatihan dan keahlian independensi dan penggunaan kemahiran profesional. Tesis.

Peraturan Menteri Dalam Negeri No. 64 Tahun 2007, tentang Pedoman Teknis Organisasi dan Tata Kerja Inspektorat Provinsi dan Kabupaten/Kota. Jakarta. 2007.

Keuangan Daerah. Jakarta. 2006.

Peraturan Badan Pemeriksa Keuangan Republik Indonesia Nomor 01 Tahun 2007. Standar Pemeriksaan Keuangan Negara. Jakarta.

Peraturan Menteri Negara Pendayagunaan Aparatur Negara nomor PER/05/M.PAN/03/2008. Standar Audit Aparat Pengawasan Intern Pemerintah. Jakarta. 2008.

Peraturan Walikota Tomohon Nomor 22 Tahun 2009. Penjabaran Tugas Pokok dan Fungsi Susunan Organisasi Inspektorat Kota Tomohon. Tomohon.

Pusat Studi Ekonomi dan Kebijakan Publik (PSEKP) UGM, Reviu Laporan Keuangan, Pengalaman Praktis di Pemerintah Daerah. 2007.

Romli, Lili. 2006. Efektivitas Pemerintah Daerah Era Otonomi: Studi Kasus Efektivitas Reformasi Birokrasi dan Pelayanan Publik di Kota Semarang. Jurnal Desentralisasi Vol. 7, No. 4. 2006.

Saifuddin. 2004. Pengaruh Kompetensi dan Independensi Terhadap Opini Audit Going Concern (Studi Kuasieksperimen pada Auditor dan Mahasiswa). Semarang. Tesis. Universitas Diponegoro. Semarang.

Sapariyah, Rina Ani. 2011. Pengaruh Good Governance dan Independensi Auditor terhadap Kinerja Auditor dan Komitmen Organisasi (Survey Pada Kantor Akuntan Publik di Surakarta). STIE “AUB”, Surakarta. 2011.

Singgih, EM, dan IR Bawono, 2010. Pengaruh Independensi, Pengalaman, Due Professional Care dan Akuntabilitas terhadap Kualitas Audit (Studi pada Auditor di KAP "Big 
Four" di Indonesia). Universitas Jenderal Soedirman pada Simposium Nasional Akuntansi XIII, Purwokerto.

Tim Peneliti UNSRAT, Pemda SULUT, dan staf Bank Dunia, 2011. Analisis Keuangan Publik Provinsi Sulawesi Utara 2011, Pengelolaan Keuangan Daerah dan Pembangunan di Bumi Nyiur Melambai. Kantor Bank Dunia Jakarta. 2011. 